\title{
Assessment of Indian cooking practices and cookwares on nutritional security: A review
}

\author{
Sarthak Saxena \\ Department of Biological Sciences and Engineering, Netaji Subhas University of Technology, \\ Delhi, India

\section{Sonia Saini} \\ Department of Nutrition Biology, School of Interdisciplinary and Applied Sciences, Central \\ University of Haryana, Mahendragarh (Haryana), India \\ Mrinal Samtiya \\ Department of Nutrition Biology, School of Interdisciplinary and Applied Sciences, Central \\ University of Haryana, Mahendragarh (Haryana), India \\ Sunita Aggarwal \\ Department of Microbiology, Institute of Home Economics ,University of Delhi, New Delhi, \\ India

\section{Tejpal Dhewa} \\ Department of Nutrition Biology, School of Interdisciplinary and Applied Sciences, Central \\ University of Haryana, Mahendragarh (Haryana), India \\ Shalini Sehgal* i \\ Department of Food Technology, Bhaskaracharya College of Applied Sciences, University of \\ Delhi, New Delhi, India \\ *Corresponding author. Email: shalinisehgal72@gmail.com; tejpaldhewa@gmail.com
}

\section{How to Cite}

Saxena, S. et al. (2021). Assessment of Indian cooking practices and cookwares on nutritional security: A review. Journal of Applied and Natural Science, 13(1): 357 - 372. https://doi.org/10.31018/jans.v13i1.2535

\begin{abstract}
Food provides us nutrients and the energy required for growth, reproduction, and maintenance. Energy is required to perform all voluntary and involuntary activities like digestion, respiration, circulation, carrying out professional, household and recreational activities. Despite having rich food diversity, we are using only a few items as our staple food. With the adoption of eastern cooking practices and cookwares, risk of both pre-and post-transitional diseases like diabetes, cardiovascular diseases, malnutrition, obesity, etc. has increased significantly. Aluminium toxicity and nutrients breakdown has become a common problem in pressure cooking. To overcome this problem, it is important to shift from the modernized cooking methods to our traditional cooking practices, i.e., use of earthen cookwares, clay pots and some selected metal utensils, e.g., copper, iron, brass, etc. It has been shown that earthen, copper, iron, and soapstone cookwares do not leach toxic trace elements into the food and enhance the sensory qualities without decreasing the food nutrients. Adoption of traditional Indian cooking practices (such as fermentation, roasting, germination, etc.), cookwares (such as earthen, copper, iron, soapstone, etc.) and increasing the consumption of healthy diet grains like millets, etc. can easily combat the pre-and post-transition health problems in India, effectively. This review would provide a deep understanding to the people to decide the best cookware and cooking processes that will improve their health and provide ample nutritional value to them.
\end{abstract}

Keywords: Cookwares, Earthen, food, Metal toxicity, Millets, Nutri-cereals, Underutilized food

\section{INTRODUCTION}

India is leading the world in many sectors. Indian culture, tradition, heritage, values, and food are rich in almost all things. Eating is a physiological necessity for growth and a central component of travelling
(Duttagupta, 2013). Indian food is famous for its wide variety from Kashmir to Kanyakumari, and from Bhuj to Itanagar. It consists of numerous spices, millets, and herbs that we are consuming since ancient times. In an era of modernization, all of us want to live a luxurious life and, hence, achieve a significant increase in our 
per capita income, literacy, urbanization, and poverty decrease. On the contrary, in such competitive situations, people are also losing their valuable day-to-day cultural and traditional practices (Pingali et al., 2019). In the current scenario, due to shortage of time and busy schedule, people are attracted to fast cooking practices or ready to eat food and in the process do forget their traditional food knowledge and values associated with it. People are losing or trying to get rid of them for their comfort and have started preferring ready to eat foods, preferring noodles over poha, and herbal tea instead of chach, which is initiating globalization (Simi and Matusitz, 2017). So, this rapid drift is creating some fathomable intricacies, such as pre- and post-transition problems due to malnutrition, under-nutrition, and overnutrition viz. stunting, anaemia, malnutrition, diabetes, obesity and other contemporary health problems (Chera, 2020). In the last few years, due to changing lifestyle patterns, risk of non-communicable disease such as diabetes have increased alarmingly. So, poor health has become a major issue, and people have started focusing on it in order to prevent them from such diseases (Tandon et al., 2018). The type of food products that are being consumed nowadays is not good for our health and causing several problems hence, we are expecting some quality food that can treat some basic health issues as oncological disorder and cardiovascular diseases. So, choosing a highly nutritive, inexpensive food with higher acceptance has become necessary (Nandy, 2004).

The Indian food industry is the world's $6^{\text {th }}$ largest food market growing at the Compound Annual Growth Rate (CAGR) of $9.23 \%$ and expected to reach 827 billion dollars by 2023 (Mukherjee et al., 2019). India is rich in food diversity and a leading producer of millets. Food and Agriculture Organization (FAO) data in 2018 shows that India produces around $35.7 \%$ of the worldwide millet production and is leading in the production of millet (Table 1). Millets refer to a common group of smallseeded annual grasses which belongs to the family Poaceae. India is a leading country in the production of a variety of millets, such as pearl millet, finger millet, foxtail millet, proso millet, barnyard millet, little millet, kodo millet, etc. All these food crops are rich in nutrients; however, they have become obsolete due to the contraction of our food habits towards rice and wheat. Millets are cereal crops native to Ethiopia and successfully adopted by the world (Fig. 1-C). Millets are pest resistant and can grow in diverse conditions (Thakur and Tiwari, 2019). Based on indigenous knowledge, land use and techniques, millet production is always considered pest free and does not require fumigants and pesticides. Some millets like; foxtail millets act as an anti-pest in the similar storage conditions of rice and pulses. Millets are stress-tolerant grains with the ability to grow in low-quality soil with less nutritional require- ments, tolerant to temperature variations and having a very short growing season (Malathi et al., 2016). Millets refer to the group of highly seeded small annual grass which are tolerant to drought and other extreme weather conditions. These can grow in both waterlogged and moist areas to drought affected regions and give a good yield and can grow in arid and semi-arid regions (Assefa et al., 2015; Michaelraj and Shanmugam, 2013). As compared to other cereals and staple foodrice and wheat, millets are highly nutritious crops. Millets contain a high amount of dietary fibre, proteins, essential fatty acids, some minerals viz. calcium, potassium, iron, zinc, magnesium, vitamins, mainly vitamin- $B$ complex (B3, B6 and B9). Millets also help in combating many diseases like blood pressure, cardiovascular diseases, diabetes, celiac diseases, thyroid (Ambati and Sucharitha, 2019). Due to its high nutritional qualities, these are considered as Nutri-cereals. Both dietary patterns and our history reveal that millets are the first and oldest known food crop cultivated for thousands of years by humans because, in the Middle Ages, Pauls and Romans were consuming it in place of rice (Ambati and Sucharitha, 2019). Number of evidences indicate that the millets cultivation dates back to $3500 \mathrm{BC}$ (Kim and Park, 2020). Till now, millets are playing a significant role in the traditional diet of many states of India. People from different localities and cultures consume several millet varieties. Millets are the staple food of Indians and some other African and Asian millet producing countries and consuming numerous varieties of underutilized millets, pulses and spices other than rice and wheat in food. However, due to a rapid shift in our food habits towards Eastern and Chinese fast foods, we have started consuming processed and ready to eat food and started utilizing fortified foods instead of our pre-existing underutilized food crops (Nandy, 2004).

Table 1. Top ten millet producer countries of 2018.

\begin{tabular}{llll}
\hline S.N. & Country & $\begin{array}{l}\text { Production } \\
\text { (Tones) }\end{array}$ & $\begin{array}{l}\text { Production } \\
\text { (\%) }\end{array}$ \\
\hline 1 & India & $11,640,000$ & 35.7 \\
2 & Niger & $3,856,344$ & 11.8 \\
3 & Sudan & $2,647,000$ & 8.1 \\
4 & Nigeria & $2,240,744$ & 6.8 \\
5 & Mali & $1,840,321$ & 5.6 \\
6 & China & $1,566,363$ & 4.8 \\
7 & China, main- & $1,565,965$ & 4.8 \\
& land & & \\
8 & Burkina Faso & $1,189,079$ & 3.6 \\
9 & Ethiopia & 982,958 & 3.0 \\
10 & Chad & 756,616 & 2.3 \\
World-wide millet & $32,585,735$ & \\
produced in 2018 &
\end{tabular}

Source: FAOSTAT-2018, "FAOSTAT_data_12-26-2020" http://www.fao.org/faostat/en/\#data/QC 
So, ironically most of these underutilized millets were in use as fodder (Kumar et al., 2012) and in alcohol production (Wu et al., 2016) which can help us to conquer the modernized problems i.e., pre- and posttranslational diseases. So, the Government has announced a millets revolution in India. Since 9000 BC before the aggrandization of hard metal or metal pots, earthen cooking pots were the major utensil known and used by the humans (Frink and Harry, 2008). People are using earthen cookwares from an ancient time and earthen cookwares cooked food is reported more effective in terms of nutrient enhancement, taste and texture acceptability. Our history and archaeology have revealed that we were cooking our food in mud pots to gold or silver vessels, from iron to copper and brass utensils (Trivedi et al., 2017) but now we have started using aluminium and non-stick utensils in order to avoid inconveniences in cooking, leakage and break because metal utensils are durable and attractive. Undoubtedly cooking in metal utensils is fast and they are good with durability and handling, but they nowhere stand with the nutritive value and possess potential hazard of releasing bis-phenol A. Due to the excessive use of aluminium and non-stick utensils, we cannot receive the proper amount of nutrition, vitamins, protein, fibre, antioxidants etc., because aluminium and non-stick utensils result in nutrients loss, metal toxicity, or change in texture, colour and properties of food. The Global Hunger Index (GHI) 2019 has given us very low merit (GHI, 2019). In 21 out of 29 states more than $30 \%$ children under 5 years of age are stunted and in 22 states more than $10 \%$ of children died below 5 years. In 22 states more than $50 \%$ of women are anaemic, but in only 5 out of 29 Indian states high-level nutrition missions are being run to cope with these problems. According to the latest reports, an average of $34.68 \%$ of children under 5 years of age are stunted while an average of $13.256 \%$ of children are wasted in India. On the other hand, the nutrition rate, obesity, diabetes, and cardiovascular diseases are also increasing alarmingly (Table 2). The United Nations Children's Emergency Fund's (UNICEF) latest report-2019 has revealed that the mortality rate of new borns is $8.8 \%$ and $68 \%$ deaths of kids underneath 5 years occurs due to malnutrition in India. The report also states that every second child below 5 years is affected by some form of malnutrition (UNICEF, 2019; UNICEF-WHO-The World Bank, 2019). Besides, India has become the major contributor to the growth of diabetic people and continuous increase in diabetes patients is projecting India as the Diabetic Capital of the world. The Global Heart Initiative of the World Health Organization (GHIWHO) has indicated that $80 \%$ of deaths due to cardiovascular disease occur in middle and low pay nations (GHI-WHO, 2019). Due to the aforementioned scenario and increase in consumer's awareness, the demand of nutrient-rich food and functional food is increasing expeditiously that has turned food industries to think innovatively. To strengthen our efforts against food crisis, pre- and post- progress problems and for encouraging the farmers towards millet production, Indian Government has been successful in sponsoring a resolution in UNGA supported by 70 nations for declarling 2023 as International Year of Millets. Escalating trend of millet bio-fortification and multi-grain flour is causing a notable increase in millet production (Birania et al., 2020) and it has increased 3-fold as compared to 1960s in which 2-fold increase in the case of rice (Figure 1-D). Thus, we are combating these basic as well as modern problems by utilizing our traditional, indigenous knowledge and using our underutilized millets along with the traditional cooking practices in order to cook nutritive food (Pennington and Schoen, 1995). Indian culture is very rich in its heritage; our indigenous practices are having more scientific explanations than others. Therefore, the present review deciphers the basic Indian culinary practices that can fight pre- and posttransition diseases in terms of grains, cooking practices and cookwares. This review will help the scientists and researchers and is also of societal importance due to the issues addressed here.

\section{Millets: a nutri-cereal}

Millets have a great potential to become small- and large-scale supplements of alkaline nature and act as the best fortification agent (fortificant). Millets have the power to combat cell and tissue injuries. It contains phenolic mixer and lecithin. Millets lower the harmful cholesterol like LDL, VLDL, triglycerides etc., and lessen the danger of numerous malignant growths (tumour or cancer) and cardiovascular diseases. Millets containing significant amounts of fat, protein, nutrients, vitamins, minerals, dietary fibre (Table 3 ), HDL, phenols, flavonoids, antioxidants, cancer preventing agents, and gluten-free, are called Nutri-grains (Michaelraj and Shanmugam, 2013; Saini et al., 2021). Barnyard millet effectively reduces blood sugar level and prevents us from celiac diseases due to its glutenfree nature (Rao et al., 2018). Watanabe (1999), has isolated three antioxidative phenolic compounds, one serotonin derivative and two flavonoids that shows its strong antioxidative activity. Luteolin, tricin and serotonin are its major anti-cancerous, anti-diabetic and antirheumatic compounds (Thakur and Tiwari, 2019). Finger millet is considered as the best diabetic food that controls blood sugar level and hyperglycaemia (Rao et al., 2018). Millets contain catechins, daidzein, epicatechin, epigallocatechin, galactocatechin, myricetin, kempherol, tricin, luteolin, taxifolin, vitexin, pyrocyanidin B1, apigenin and pyrocyanidin B2 that all are vital in the treatment of cardiovascular diseases and diabetes. Finger millets are also antimicrobial and anti- 
Table 2. State-wise data health and nutrition data of India.

\begin{tabular}{|c|c|c|c|c|c|}
\hline S. No. & State & $\begin{array}{l}\text { Children under } 5 \\
\text { years (stunted) } \\
\text { (in \%) }\end{array}$ & $\begin{array}{l}\text { Children under } 5 \\
\text { years (wasted) } \\
\text { (in \%) }\end{array}$ & $\begin{array}{l}\text { Women with ane- } \\
\text { mia (15-49 years) } \\
\text { (in \%) }\end{array}$ & $\begin{array}{l}\text { Does state have a } \\
\text { high-level nutri- } \\
\text { tion mission? }\end{array}$ \\
\hline 1 & Arunachal Pradesh & 28 & 17 & 1 & No \\
\hline 2 & Andra Pradesh & 34.5 & 19 & 68.1 & No \\
\hline 3 & Assam & 40.6 & 9.7 & 69.5 & No \\
\hline 4 & Bihar & 49.4 & 13.1 & 67.4 & No \\
\hline 5 & Chhattisgarh & 43 & 12.9 & 57.5 & No \\
\hline 6 & Delhi & 29.1 & 14.3 & 44.3 & No \\
\hline 7 & Gujarat & 41.6 & 18.7 & 55.3 & YES \\
\hline 8 & Goa & 21.3 & 15.4 & 63.4 & No \\
\hline 9 & Haryana & 36.5 & 8.8 & 57.7 & No \\
\hline 10 & Himachal Pradesh & 34.2 & 10.1 & 44 & No \\
\hline 11 & $\begin{array}{l}\text { Jammu and } \\
\text { Kashmir }\end{array}$ & 31.7 & 7.1 & 52.1 & No \\
\hline 12 & Jharkhand & 47.40 & 15.6 & 69.5 & YES \\
\hline 13 & Karnataka & 34.2 & 17 & 62.5 & YES \\
\hline 14 & Kerala & 19.4 & 15.5 & 32.7 & No \\
\hline 15 & Madhya Pradesh & 41.5 & 17.5 & 56 & YES \\
\hline 16 & Maharashtra & 35.4 & 18.6 & 65.3 & YES \\
\hline 17 & Meghalaya & 42.9 & 13.1 & 53.9 & No \\
\hline 18 & Mizoram & 26.9 & 14.3 & 64.1 & No \\
\hline 19 & Manipur & 33.2 & 7.1 & 65.3 & No \\
\hline 20 & Nagaland & 29.1 & 11.8 & 50.2 & No \\
\hline 21 & Orisssa & 38.2 & 18.3 & 61.2 & No \\
\hline 22 & Punjab & 30.5 & 8.7 & 52.7 & No \\
\hline 23 & Rajasthan & 36.4 & 14.1 & 53.1 & No \\
\hline 24 & Sikkim & 28 & 5.1 & 70.6 & No \\
\hline 25 & Tamilnadu & 23.3 & 19 & 49.2 & No \\
\hline 26 & Tripura & 31 & 17.1 & 45.6 & No \\
\hline 27 & Uttar Pradesh & 50.4 & 10 & 49.9 & YES \\
\hline 28 & Uttarakhand & 34 & 9.3 & 55.2 & No \\
\hline \multirow[t]{2}{*}{29} & West Bengal & 34.7 & 15.3 & 76.3 & No \\
\hline & Average value & 34.68 & 13.56 & 55.62 & $5 Y: 24 N$ \\
\hline
\end{tabular}

Source: India Health Report on Nutrition 2015 Explore state level data, http://www.transformnutrition.org/indiahealth-report-on-nutrition2015/india-health-report-on-nutrition-2015-explore-state-level-data/

tumorigenic in nature (Thakur and Tiwari, 2019). Foxtail millet contains apigenin, catechin, kempherol and quercetin that helps in combating cardiovascular disease, diabetes and dyslipidemia. These are anti-microbial, anti-tumorigenic, anti-cancerous and help in body detoxification (Thakur and Tiwari, 2019). Kodo millets contain lecithin which is effective in strengthening our nervous system (Rao et al., 2018). Kodo millet consumption is good for postmenopausal women and those suffering from high cholesterol problems, heart related diseases and high blood pressure. Kodo millets can also be used in rendering general debility, haemorrhages, hepatopathy and inflation (Jain et al., 2010). Little millets are B group vitamins, phosphorus and ironrich. Germinating little millets produces the $\alpha$-amylase of higher purity with higher yield (Usha et al., 2011). The soluble fraction of little millets contains $80 \%$ of flavonoid (luteolin and kaempferol) and phenolic (ferulic, caffic and sinapic acids) contents (Pradeep and Sreerama, 2015). Millets contain a good amount of cop- 
Saxena, S. et al. / J. Appl. \& Nat. Sci. 13(1): 357 - 372 (2021)

\begin{tabular}{|c|c|c|c|c|c|c|c|c|c|c|}
\hline S. No. & Crops & $\begin{array}{l}\text { Common } \\
\text { Name }\end{array}$ & $\begin{array}{l}\text { Scientific } \\
\text { Name }\end{array}$ & $\begin{array}{l}\text { Calcium } \\
\text { (mg) }\end{array}$ & $\begin{array}{l}\text { Fat } \\
\text { (gm) }\end{array}$ & $\begin{array}{l}\text { Fiber } \\
\text { ((gm) }\end{array}$ & $\begin{array}{l}\text { Iron } \\
\text { (mg) }\end{array}$ & $\begin{array}{l}\text { Minerals } \\
(\mathrm{mg})\end{array}$ & $\begin{array}{l}\text { Protein } \\
\text { (gm) }\end{array}$ & $\begin{array}{l}\text { Energy } \\
\text { (Kcal) }\end{array}$ \\
\hline 1 & $\begin{array}{l}\text { Barnyard } \\
\text { Millet }\end{array}$ & $\begin{array}{l}\text { Banti, oodalu, } \\
\text { shyama, swank }\end{array}$ & $\begin{array}{l}\text { Echinochloa } \\
\text { spp. }\end{array}$ & 11 & 3.9 & 10.1 & 15.2 & 4.4 & 11.2 & 342 \\
\hline 2 & $\begin{array}{l}\text { Finger } \\
\text { Millet }\end{array}$ & $\begin{array}{l}\text { Ragi, mandua, } \\
\text { nachni, mandiya, }\end{array}$ & $\begin{array}{l}\text { Eleusine } \\
\text { coracana }\end{array}$ & 34 & 1.5 & 1.5 & 3.9 & 2.7 & 7.3 & 336 \\
\hline 3 & $\begin{array}{l}\text { Foxtail } \\
\text { Millet }\end{array}$ & $\begin{array}{l}\text { Kangani, kanghzu, } \\
\text { navane, tanai }\end{array}$ & Setaria italica & 31 & 4 & 8 & 2.8 & 3.3 & 12.3 & 473 \\
\hline 4 & $\begin{array}{l}\text { Kodo } \\
\text { Millet }\end{array}$ & $\begin{array}{l}\text { Anika, kodon, } \\
\text { Kodra, varaku }\end{array}$ & $\begin{array}{l}\text { Paspalum } \\
\text { scrobiculatum }\end{array}$ & 27 & 3.6 & 9 & 0.5 & 2.6 & 8.3 & 309 \\
\hline 5 & $\begin{array}{l}\text { Little } \\
\text { Millet }\end{array}$ & $\begin{array}{l}\text { Gajrao, kutki, } \\
\text { samalu, sava }\end{array}$ & $\begin{array}{l}\text { Panicum } \\
\text { miliare }\end{array}$ & 17 & 5.2 & 7.6 & 9.3 & 1.5 & 7.7 & 207 \\
\hline 6 & $\begin{array}{l}\text { Pearl } \\
\text { Millet }\end{array}$ & $\begin{array}{l}\text { Bajra, bajri, } \\
\text { Cumbu, sajja }\end{array}$ & $\begin{array}{l}\text { Pennisetum } \\
\text { glaucum }\end{array}$ & 38 & 4.8 & 1.3 & 16.9 & 2.3 & 10.6 & 378 \\
\hline 7 & $\begin{array}{l}\text { Proso } \\
\text { Millet }\end{array}$ & $\begin{array}{l}\text { Bachari, baragu, } \\
\text { chena, vari }\end{array}$ & $\begin{array}{l}\text { Panicum } \\
\text { miliaceum }\end{array}$ & 14 & 2.9 & 2.2 & 0.8 & 1.9 & 12.5 & 356 \\
\hline 8 & Sorghum & $\begin{array}{l}\text { Cholam, jola, } \\
\text { jowar, rotla }\end{array}$ & $\begin{array}{l}\text { Sorgum } \\
\text { bicolor }\end{array}$ & 25 & 3.1 & 2 & 5.4 & 1.6 & 10.4 & 329 \\
\hline
\end{tabular}

Source: Thakur and Tiwari ( 2019)

per, folate, zinc, magnesium, iron, calcium, unsaturated fatty acids and vitamin B complex (Rao et al., 2018). Pearl millet shows protective activity against DNA damage. Due to the higher concentration of folate, it can also be used as fortificant to fortify the foods for anaemic population. Magnesium fosters migraine treatment and can reduce asthmatic patients' respiratory problems (Ambati and Sucharitha, 2019). Proso millets are good for bones and help in combating blood-pressure, dyslipidemia, breast cancer and cardiovascular diseases (Rao et al., 2018). Its carotenoids extract has high cellular antioxidant activity as compared to fruits and vegetables. Proso millets also have higher dose dependent anti-proliferative activity against human liver cancer cells and contain around $65 \%$ of phenolic compounds and some bioactive phytochemical compounds like ferulic acid, caffeic acid, chlorogenic acid and syringic acid beneficial for human health (Zhang et al., 2014a). Quinoa contains a high amount of protein, minerals, dietary fibre and vitamins that help in combating diabetes, celiac diseases, protein-energy malnutrition, dyslipidemia and cardiovascular disease ( $\mathrm{Li}$ et al., 2018). It is rich in minerals and contains methionine and lysine that are lacking in cereals. Due to high amounts of oil such as omega- 6 fatty acid, vitamin-B and vitamin-E, it is also considered as an oil crop (James, 2009). The nutritional qualities of sorghum are better than rice and it contains folic acid, $\beta$-carotene, fibre, thiamine and riboflavin (Rao et al., 2018). Sorghum is rich in flavonoids, condensed tannins and phenolic acids. Its pigment and antioxidant properties are competitive to vegetables and fruits. It is anti-carcinogenic and lowers the risk of oesophageal cancer. However, compounds responsible for its anti-carcinogenicity are still unexplored (Dykes and Rooney, 2006).

\section{Effect of cooking methods}

There is less or no information available to show the effect of cooking on nutritional composition, especially on water-soluble vitamins and proteins of food. Indian culinary is wide and for a long-time, we are incessantly consuming food cooked by germination, fermentation, boiling, roasting, frying and pressure cooking. All these cooking methods draft a unique impact on food in terms of their nutritional and sensory properties. The cooking method affects the nutrients, minerals, vitamins, proteins, fats, amino acid, phenolic and flavonoid concentration in food. So, researchers started exploring the potential factors to enhance food's nutritional quality (Otemuyiwa et al., 2018).

\section{Germination}

Eating sprouts is considered a more nutritive and healthy food supplement in India. Sprouts are an excellent source of amino acids, proteins and vitamins and some phytochemicals (Ghani et al., 2016). Germination is an old practice and done by soaking. It enhances the bio-accessibility of minerals and reduces the level of anti-nutritional factors such as oxalate and phytate (Suma and Urooj, 2014). It positively increases the antioxidant activity, dietary fibres, total phenolic, total flavonoid content (Sharma et al., 2016) and also affects the concentration of free amino acids and non-protein amino acids depending on the type of crop (Kuo et al., 2004). Gamma-aminobutyric acid (GABA) content is always increased after germination (Suma and Urooj, 2014; Sharma et al., 2016; Kuo et al., 2004) which regulate the blood pressure, cardiovascular diseases, alleviate the pain and anxiety (Bai et al., 2008). Some new bioactive compounds viz. butyl-6,9,12,15octadecatetraenoate, hexa-decanoic acid, hexa- 
Saxena, S. et al. / J. Appl. \& Nat. Sci. 13(1): 357 - 372 (2021)

Table 4. Advantages, disadvantage and health anomalies pertaining to the cookware/utensils.

\begin{tabular}{|c|c|c|c|c|}
\hline S. No. & Cookware & Advantages & Disadvantages & Health Anomalies \\
\hline 1 & $\begin{array}{l}\text { Aluminium } \\
\text { Cookware }\end{array}$ & $\begin{array}{l}\text { - Inexpensive } \\
\text { - Lightweight } \\
\text { - Easy to clean } \\
\text { - Thermally responsive } \\
\text { - Energy saver } \\
\text { - Hygienic } \\
\text { - Corrosion resistant } \\
\text { - Recyclable }\end{array}$ & $\begin{array}{l}\text { - High leaching } \\
\text { - Interacts with acidic food } \\
\text { - Leaches } \mathrm{Cd}, \mathrm{Pb} \text { and other } \\
\text { harmful heavy metals } \\
\text { - Long cooking or storage leads } \\
\text { to the higher } \\
\text { aluminium leaching into food }\end{array}$ & $\begin{array}{l}\text { - Arthralgia } \\
\text { - Alzheimer } \\
\text { - Auto immune diseases } \\
\text { - Breast cancer } \\
\text { - Carcinogenic } \\
\text { - Chronic fatigue } \\
\text { - Chronic renal failure } \\
\text { - Dementia } \\
\text { - Myalgia } \\
\text { - Muscle weekness } \\
\text { - Neurological syndrome etc. }\end{array}$ \\
\hline 2 & $\begin{array}{l}\text { Copper } \\
\text { Cookware }\end{array}$ & $\begin{array}{l}\text { - Antimicrobial activity } \\
\text { - Effective heat } \\
\text { conduction } \\
\text { - Easy temperature } \\
\text { controlling }\end{array}$ & $\begin{array}{l}\text { - High leaching may occur if } \\
\text { cooked acidic foods in cooper } \\
\text { cookware } \\
\text { - Rusting and corrosion occurs } \\
\text { easily }\end{array}$ & $\begin{array}{l}\text { High copper intake may cause; } \\
\text { - Alzhiemer } \\
\text { - Cirrhosis } \\
\text { - Copper toxicosis } \\
\text { - Diabetes } \\
\text { - Tumor inducing }\end{array}$ \\
\hline 3 & $\begin{array}{l}\text { Earthen/ } \\
\text { ceramic } \\
\text { Cookware }\end{array}$ & $\begin{array}{l}\text { - Inexpensive } \\
\text { - Enhances the aroma, } \\
\text { texture colour and other } \\
\text { sensory qualities of food. } \\
\text { - Retains the nutrition of } \\
\text { food } \\
\text { - Keeps the storing } \\
\text { materials cool } \\
\text { - Easy cleaning } \\
\text { - High temperature } \\
\text { resistant } \\
\text { - Wear and corrosion free } \\
\text { - Traditional pride }\end{array}$ & $\begin{array}{l}\text { - Inner polishing may lead to } \mathrm{Pb} \\
\text { and Cd leaching } \\
\text { - Heavy weight } \\
\text { - Delicate to handle } \\
\text { because easily breakable } \\
\text { - Leakage may occur } \\
\text { easily }\end{array}$ & $\begin{array}{l}\text { - Polishing or clazing the inner surface } \\
\text { may present the } \mathrm{Pb} \text { and Cd toxicity. }\end{array}$ \\
\hline 4 & Iron Cookware & $\begin{array}{l}\text { - High heating capacity } \\
\text { - Releases less iron in food } \\
\text { which is necessary for the } \\
\text { body } \\
\text { - Retains heat for long time } \\
\text { and keeps the food warm }\end{array}$ & $\begin{array}{l}\text { - Easy corrosion } \\
\text { - Reduces the natural } \\
\text { aroma, colour and texture } \\
\text { of food }\end{array}$ & $\begin{array}{l}\text { High iron intake may cause: } \\
\text { - Cancer initiation } \\
\text { - Neuro degeneration } \\
\text { - Tissue damage etc. }\end{array}$ \\
\hline 5 & $\begin{array}{l}\text { Non-stick or } \\
\text { anodized } \\
\text { Cookware }\end{array}$ & $\begin{array}{l}\text { - Easy to handle } \\
\text { - Aesthetic appearance } \\
\text { - Hard and durable } \\
\text { - Convenient cooking } \\
\text { - Easy to clean }\end{array}$ & $\begin{array}{l}\text { - Coatings breaks, unwind or } \\
\text { flake off after some times } \\
\text { - Leaches highly toxic PPFASs } \\
\text { compounds in food }\end{array}$ & $\begin{array}{l}\text { Leaches Perflurooctanonic acid (PFOA) } \\
\text { which is carcinogenic. } \\
\text { - PPFASs may lead to the: } \\
\text { - Increases cholesterol level } \\
\text { - Lowers the pregnancy chances } \\
\text { - Reduces the vaccine generated dis- } \\
\text { ease control } \\
\text { - Harmful effect on tests and kidney }\end{array}$ \\
\hline 6 & Stainless steel & $\begin{array}{l}\text { - Light weight } \\
\text { - Aesthetic appearance } \\
\text { - Durable } \\
\text { - Stores energy for long } \\
\text { - Kime } \\
\text { - Keeps food warm } \\
\text { - Contains less toxic } \\
\text { compounds as compare to } \\
\text { - Aluminium or non-sticks } \\
\text { - Less susceptible to } \\
\text { leaching }\end{array}$ & $\begin{array}{l}\text { - Chromium leaching may } \\
\text { possess high health risk } \\
\text { - Alloy contents may leach into } \\
\text { food }\end{array}$ & $\begin{array}{l}\text { Leaches chromium which may cause: } \\
\text { - Eryptosis } \\
\text { - Dermatitis } \\
\text { - RBC damage etc. }\end{array}$ \\
\hline 7 & Soapstone & $\begin{array}{l}\text { - High energy storage po- } \\
\text { tential } \\
\text { - Heat shock proof } \\
\text { - Durable } \\
\text { - Hard to brake } \\
\text { - Leaches calcium and } \\
\text { magnesium into food with- } \\
\text { in the range }\end{array}$ & $\begin{array}{l}\text { - Heavy weight } \\
\text { - Delicate handling } \\
\text { - Inconvenient washing }\end{array}$ & $\begin{array}{l}\text { - High calcium and } \\
\text { magnesium intake } \\
\text { affects the bones }\end{array}$ \\
\hline
\end{tabular}

Source: (Guidetti and Simonetti 2000; Kontoghiorghes and Kontoghiorghe 2020; Duwe and Niedzwiecki 2020; Zhang et al. 2014a,b; Quan 2019; Ingle et al. 2018); Anderko and Pennea 2020; Quintaes et al. 2002; Anthony et al. 2013; Trivedi et al. 2017) 
decanoic acid-methyl ester, n-propyl-9, 12, 15 octadecatrienoate, pregan,20-one-2hydroxy,5,6, epox-15 methyl, 9, O-ctadecenoicacid are also reported after germination in kodo millet (Sharma et al., 2016). Germination also lowers the glycemic index of seeds so that diabetic people can also consume it (Cornejo et al., 2015).

\section{Fermentation}

In India, fermentation is used to prepare several food items and these food items are providing food security to communities. A variety of dough, porridges and beverages are prepared by fermentation. Fermentation increases the nutritional value, total reducing and nonreducing sugars, and significantly affects the protein, vitamins, minerals and fat concentration (Khetarpaul and Chauhan, 1990). It also increases the total phenols, total flavonoids, free amino acids and other phytochemical components (Subastri et al., 2015). Fermented foods are popular because they lower the amount of anti-nutrients such as tannins, phytic acids and trypsin inhibitors. Fermented food also provides certain nutritive and therapeutic values (Samtiya et al., 2020; Farag et al., 2020). Balli et al. (2020) has demonstrated that phenolic extract of fermented millets has a high antioxidant level on human erythrocytes by an ex-vivo procedure. Another similar study has revealed that phenolic extracts of fermented millets increase the DNA damage protection activity of millets (Purewal et al., 2020). It also increases the protein digestibility of millets (Ali et al., 2003). Ezeji and Ojimelukwe (1993) have demonstrated that fermented millet feeds increase the weight gain and PFR value in rats and suggested that fermented food supports infants' growth better than other food alternatives.

\section{Roasting and frying}

Roasting is a dry cooking method preferred for its nutritional credibility. Roasted or puffed grains are consumed not only in India and South Asian countries but throughout the world. Consumption is directly dependent on the locality, food habits, convenience and availability of the type of grains e.g., popcorns are the oldest and most used roasted grain (Srivastav et al., 1990). Roasting increases the concentration of available mineral content and it has been proved by the increase in their mineral's extractability (Gahlawat and Sehgal, 1993). Roasting does not significantly affect the physicochemical properties of food grains, but it contributes to fostering its aroma and storage parameters (Griffith and CastellPerez, 1998). Modgil and Sood (2017) have demonstrated that roasting decreases the energy value, antioxidative activity, phenolic and flavonoid content. High-temperature roasting significantly decreases the phenolic content of food grains but increases its functional properties (Obadina et al., 2016). In contrast, frying is wet cooking done in hot oil or fat. Indians use ample amounts of fat in food. So, frying is the most preferred cooking practice here after pressure cooking. However, research and literature reciting its effect on the nutritional, physicochemical and sensory properties is available. Annapure et al. (1998) has stated that there is no correlation between the proximate content of food and oil composition.

\section{Microwave oven cooking}

Dry heating in small domestic furnaces and heated ovens is an old practice used in bakeries, while microwave assisted oven cooking is an emerging cooking practice in India. Yadav et al. (2012) has stated that microwave lowers the lipase activity so it extends the shelf life of millet flour at ambient conditions. Microwave-assisted millet cooking significantly affects the antioxidant activities, phenolic activities and inhibitory effect against the $\alpha$-glucosidase and $\alpha$-amylase. So, it can be used against hyperglycemia in diabetic people (Pradeep and Sreerama, 2015). Baba et al. (2016) has studied the antioxidant and anticancer activity of microwave assisted cooking and reveals that microwave roasting decreases the anticancer potential and DNA damage inhibition activity in barley. Microwave cooking increases the protein content but does not affect the physicochemical properties except for the water solubility index (WSI). WSI increases and enhances the functional properties, suggesting its industrial utilization (Kumar et al., 2020). Microwave cooking effectively reduces the level of toxins especially aflatoxins in food so considered as a healthy cooking practice (Meenatchi et al., 2015).

\section{Nutrients loss due to pressure cooking}

A Nigerian study on nutrient loss by cooking methods has revealed that various cooking methods e.g., ordinary cooking, parboiling, microwave and pressure cooking positively affect the vit $\mathrm{C}$, vit $\mathrm{B} 6$, vit $\mathrm{B} 1$ and vit B9 concentration of food. The study demonstrated that vitamins retention in parboiling was higher than conventional and microwave cooking methods. The least vitamin retention was seen in pressure cooking methods (Otemuyiwa et al., 2018). Another similar study has shown that the loss of vitamin $\mathrm{C}$ in pressure cooking was more as compared to open pan cooking of cabbage and Ethiopian green collard (Hailemariam and Wudineh, 2020). Dutta et al. (2019) has suggested that millets are rich in micronutrients and provide a balanced diet if consumed in an adequate amount. The study also implies that bioactive components (phenolic and flavonoids) of millets reduce as the temperature and pressure increases (Figure 1-E). Reduction in phenolic and flavonoid content is reported higher in pressure cooking. Another study has demonstrated that 
pressure cooking causes the denaturation of proteins, essential amino acids, carbohydrates and saturated or unsaturated fatty acids. It also implies that cooking methods directly impact the amino acid composition of food (Figure 1-F) (Seena et al., 2006). Liu et al. (2019) has studied the impacts of washing, soaking, and cooking and suggested that reduction/denaturation of vitamins occur due to high pressure and temperature. At $121^{\circ} \mathrm{C}$, thiamine losses were more than at $99^{\circ} \mathrm{C}$ or less temperature.

Cookwares: Types and effects on nutritional values Cookwares affect the nutritional composition of the food, both positively and negatively. Different metal cookwares can cause metal or trace metals toxicity (Dan and Ebong, 2013). Cookwares are made up of a variety of materials like metals, mud, stone etc. Some most commonly used cookwares are made up of gold, silver, aluminium, copper, brass, bronze, iron, steel, stainless steel, nonstick, food grade plastics, clay or soapstone (Alabi and Adeoluwa, 2020). All these cookwares have their own advantages and disadvantages in terms of durability, convenience, and cost (Table-4). Cooking in an aluminium pressure cooker leads to the breakdown of nutrients. Due to its high pressure and uneven heat circulation, pressure cookers cause the breakage/denaturation of protein, vitamins and other important minerals. So, it is essential to look back in time when people used to cook food in earthenware pots, clay pots or other handy metal cookwares that do not lead to higher nutrient loss during cooking. Earthen cookwares absorb moisture due to its porous nature and retain nutrition. They also absorb toxic substances which are neutralized by fire. Food cooked in earthen cookwares provides a comparatively high number of proteins, vitamins, minerals than cooked in aluminium pressure cooker and metal cookwares.

\section{Non-stick}

Non-stick cookwares are the most emerging cookwares throughout the world due to its lightweight, convenient handling, easy cooking practices and microwave usage. Non-stick cookwares are the metal cookware with a nonstock coating of PFASs. Per- and polyfluoroalkyl substances (PFASs) are the synthetic chemical compounds that are detrimental to the environment as well as human health (Yamijala et al., 2020). PFASs are one of the emerging concerns because its exposure may cause irregularities in growth, behaviour and learning of infants and mature children. In women, it also lowers the chances of getting pregnant, affects the immune system, increases the cholesterol level and also may reduce the vaccine generated disease protection in children (Anderko and Pennea, 2020). It also drafts an adverse effect on fish, causing toxicity and change in their swimming abilities (Menger et al., 2020). Among the PFASs, short-chain polyfluoroalkyl carboxylic acid (SC PFCA) and perfluorooctanoic acid (PFOA) are mostly detectable in polluted streams. Han et al. (2020) has demonstrated the noxious effects of SC PCFA on the liver, testes and kidney through in vivo model. The study also reveals that PFOA also causes microscopic abnormalities and decreases the thickness of the skin. An independent science review panel of United States Environmental Protection Agency (US EPA) has proposed perfluorooctanoic acid (PFOA) to be acknowledged as "likely to be a carcinogenic compound" after reviewing an in vivo study that has revealed PFOA causes death in laboratory rats (Steenland et al., 2010).

\section{Iron}

Iron is one of the essential elements for humans. It is required for the production of red blood cells. Excess iron in the body is, however, poisonous but in India the number of anaemic populations is higher. We take around $20 \%$ of the iron intake from cookwares (Health Canada, 2006). Cheng and Brittin (1991) have demonstrated that older cookwares add more iron in food than the new one and suggested that cooking in iron cookware enhances some factors that can increase the adsorption of non-heme iron which makes it more bioavailable. Due to the nutritional advantages of cooking food in iron cookware, food scientists and researchers are recommending it as a potential remedy to cope up with anaemia. However, another study has revealed that cooking in iron cookwares doesn't affect the sensory qualities but decreases the colour and flavour, leading to declining consumers' acceptance (Park and Brittin, 2000). Quintaes et al. (2007) has reported that cast iron cookware cooked food drastically improves the iron level and decreases anaemia in the population. The study also implicates that cooking of low pH foods is more likely to add higher amounts of iron and possibly manganese. In humans, due to iron imbalance, a variety of diseases occur. Other than anaemia, lack of iron can cause hemoglobinopathies, the most common genetic disorder and idiopathic hemochromatosis. However, excess iron content can also lead to neurodegeneration, cancer initiation and tissue damage in pathological conditions (Kontoghiorghes and Kontoghiorghe, 2020).

\section{Aluminium}

Aluminium is the third most common element available on earth's crust. Variety of aluminium cookwares are currently in use. However, its corrosion rate increases with the salt concentration and it starts leaching ( $\mathrm{Al}$ Zubaidy et al., 2011). Before the British rule, Indians were using copper, iron and brass cookwares. Aluminium was first introduced in Indian jails but later spread to all parts of the country due to its lightweight, fast cooking and convenience. Aluminium based pressure 
cookers (Figure 1-A) and other cooking vessels have become the most commonly used cookwares in the current era. However, many studies have reported the leaching and nutrient loss during cooking (Semwal et al., 2006). Aluminium is a toxic heavy metal that is nonessential to humans and not taking part in the metabolism of the body for functioning and maintenance. It is present in human food from animals as well as plant sources. Various plants grown in acidic soils uptake aluminium and accumulate it (Stahl et al., 2017). Neelam et al. (2000) has shown that cooking in aluminium cookwares increases the aluminium intake in humans significantly. Besides, it aids more aluminium burden in food if stored in aluminium utensils. Duwe and Niedzwiecki (2020) have precisely accentuated the adverse effects of aluminium on mitochondrial energy production and its role in causing alzheimer, breast cancer, dementia, autoimmune syndrome, myalgia, chronic fatigue, arthralgia, muscle weakness and cognitive dysfunction. Another study has revealed that in low- and middle-income countries people use low cost locally casted aluminium cookwares that are basically manufactured by recycling the computer hard disk cover, radiators, engine parts of motorbike, cans, construction materials, some part of computers and other metal scraps. These cookwares leach the aluminium, lead and cadmium into the food and can possess serious health issues (Weidenhamer et al., 2014). Street et al. (2020) has listed and identified the 18 metals viz. Fe, Cd, Hg, Pb, Co, Cr, Zn, Sn, $\mathrm{Cu}, \mathrm{Mn}, \mathrm{Se}, \mathrm{As}, \mathrm{Ag}, \mathrm{Ba}, \mathrm{Mo}, \mathrm{Ni}, \mathrm{Sb}$ and $\mathrm{V}$ in these artisanal cookwares. Aluminium toxicity in diabetic patients is comparatively higher. It is reported that the patients of diabetes mellitus type- 2 are associated with the increased risk of renal dysfunctioning, cardiovascular disease, atherosclerosis and many more. Aluminium is the only element found in elevated concentration in neurofibrillary tangles. The evidence far indicated that aluminium is toxic to brain and it is possible that it has a pathogenic role in alzheimer's disease (Krishnan et al., 1988). Rittirong and Saenboonruang (2018) have demonstrated the carcinogenic and anticarcinogenic activities of pressure-cooked rice. Aluminium foils are the most emerging food wrapping item worldwide, but it gets leached to the extent that can cause serious potential illness in smaller children and in people suffering from chronic renal failure (Dordevic et al., 2019).

\section{Stainless steel}

Stainless steel is an iron based alloy which contains up to $30 \%$ chromium (Reardon, 2011). Stainless steel has become one of the most commonly used metals in the cookware industry due to its various advantages like inexpensiveness, durability, light weight, easy to handle, cooking conveniences, high heat and wear resistance properties (Health Canada, 2006). Stainless steel cookware also leaches aluminium but less than aluminium cookwares, hence, does not create any harmful impact on humans (Dan and Ebong, 2013). During cooking in new cookwares, leaching is higher, and chromium and nickel concentrations increase 35 and 34 folds, respectively (Kamerud et al., 2013). Hexavalent chromium can cause eryptosis, and increased rapid ATP consumption and RBC damage (Zhang et al., 2014b). Quan (2019) has stated that the average intake of nickel is about $300 \mu \mathrm{g}$ per day, demonstrating that present stainless cups leaches nickel to the extent that can cause dermatitis. Leaching of metal irons from coffee machines and electric kettles is also a point of concern as it releases the $\mathrm{Cr}, \mathrm{Ni}, \mathrm{Mn}, \mathrm{Pb}$ and $\mathrm{Zn}$ in the fluid (Müller et al., 2015).

Kandavel et al. (2015) have reported that different cookwares affect the boiling of water significantly and demonstrated that cookwares made up of teflon and stainless steel have increased the fluoride level after boiling while it decreases if boiled in earthen, aluminium and glass vessels. So, utilization of stainless steel and teflon cookwares in direct cooking can toxify the food. Roy et al. (2012) has shown that stainless steel vessels give more yield during fermentation of Bakhar-Handia as compared to plastic vessels.

\section{Copper}

Copper is a metal available in abundance and used in plumbing, storage, drinking and cooking vessels. The use of copper gets popularize due to its high thermal conductivity, aesthetic appearance, light weight and antimicrobial activity. WHO has classified copper (Cu) as an essential trace metal for humans and it amounts around $70-100 \mathrm{mg}$ in the human body. Copper tableware viz. plates, bowls, jugs, spoons and mugs are frequently used as compared to the copper cookwares. Tableware too leaches the copper in food and beverages and it is helpful for humans if within the limits (Ishiwata et al., 1986). Jiang et al. (2019) have demonstrated that nano copper polypropylene composite food wrapping film has higher antimicrobial activity against Bacillus subtilis, Escherichia coli, Shigella castellani and Staphylococcus aureus. Copper cookwares and foils leach the copper and it is dependent on the $\mathrm{pH}$ and temperature of the food and it doesn't get affected by the long term continued utensil cleaning (Koontz et al., 2020). Copper is present in almost all sort of human tissues. It is absorbed in the human gut and stored in liver, brain, heart, kidney and muscles after transport (Bhattacharya et al., 2016). Copper is an essential micro-element required for many biological processes of humans and other life forms like growth and survival. It also allows some enzymes for their proper functioning. So, its use is recommended since vedic-period. Lack of copper in humans causes the menke's disease, cardiovascular diseases, occipital horn syndrome, acerulo- 

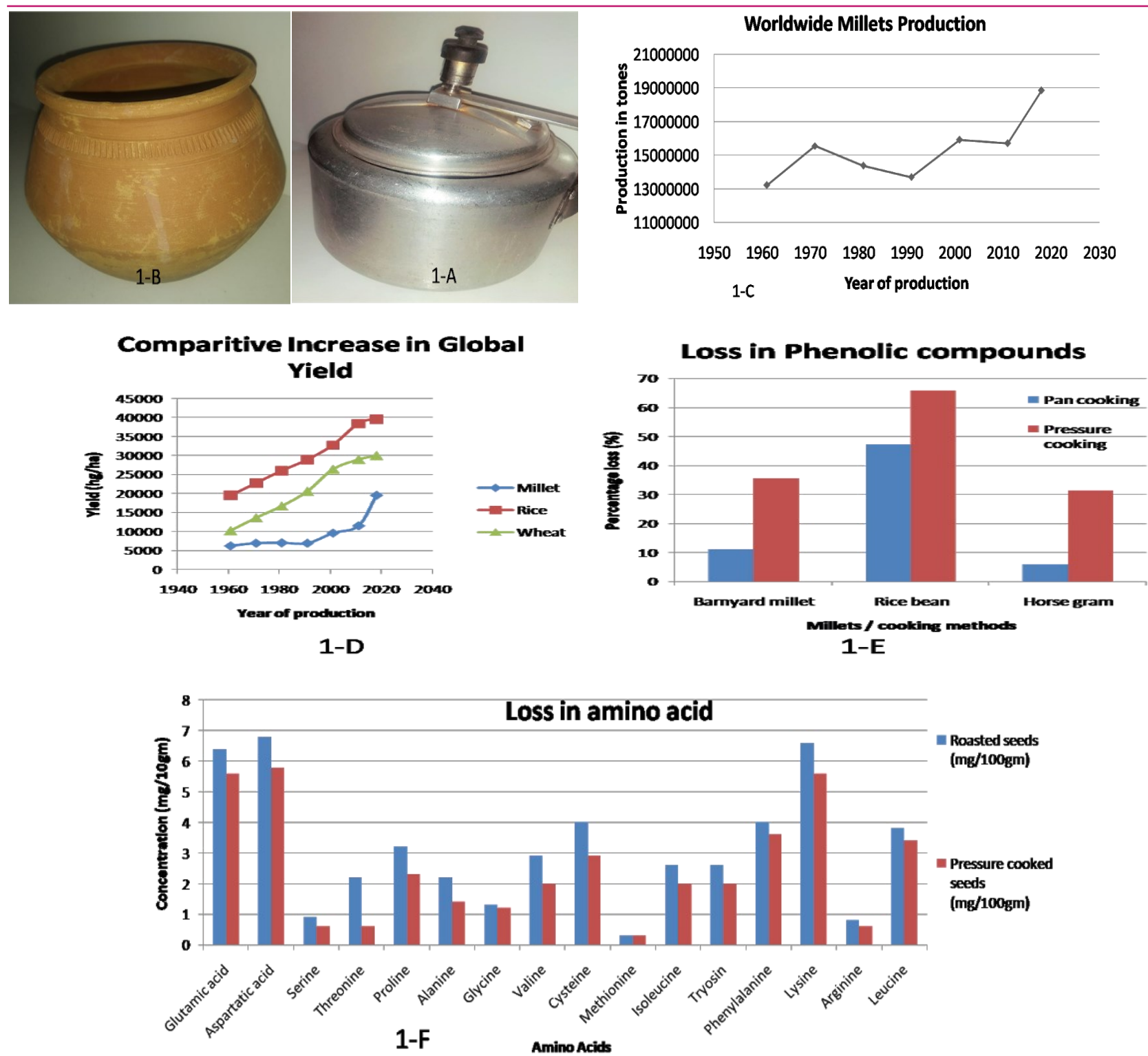

Fig. 1. 1A-Aluminium pressure cooker, 1B-Earthen cookware, $1 \mathrm{C}$-worldwide millet production trend (FAOSTAT Data 2018), 1D-Worldwide comparative yield of rice, wheat and millets (FAOSTAT 2018), 1E- loss of phenolic compounds in pan and pressure cooking (Dutta et al. 2019), 1F-Comparative loss in amino acid by roasting and pressure cooking (Seena et al. 2006).

plasminemia and zinc induced myeloneuropathy etc. whereas excess copper causes wilson's and nonwilson's diseases like Indian childhood cirrhosis, copper toxicosis, diabetes, alzheimer's, etc. (Ingle et al., 2018). Higher copper accumulation in tissues leads to cancer development by angiogenesis because copper (Cu) stimulates the migration and proliferation of endothelial cells required for secreting various angiogenesis factors by tumor cells (Gupte and Mumper, 2009; Lowndes and Harris, 2005). On the contrary, researchers are also focusing on turning the tumor inductive copper into anti-cancer by using high throughput chemistry (Wang et al., 2010). Tang et al. (2013) has demonstrated that dietary copper improves the growth, adsorption, digestive capacities and decreases the protein adsorption and lipid peroxidation

\section{Earthen}

Clay pottery is an ancient craft in India that has grown with the civilizations. Earthen or clay cookwares, storage vessels and toys are used here for a long time. Earthen cookwares/pots (Figure 1-B) are widely used by Indian villagers or tribes for cooking purposes till now. Not only nutrients but also taste, texture, color, and fragrance, earthen pots enhance all the food parameters in terms of acceptability. In traditional indigenous knowledge and Ayurveda, the use of earthen pots is recommended in many medicine and fermentation processes (Chakrabarty et al., 2010; Deori et al., 2007; Etejere and Bhat, 1985; Saxena and Dutta, 1975; Bhat 
et al., 1990; Soibam and Ayam, 2018; Wokoma and Aziagba, 2001). The heat transfer efficiency of earthen pots is higher, which helps them to keep the storing material cool. Domestic water pots for potable water usage are the most common example of this (Trivedi et al., 2017). Beverages fermented in earthen pots are more intoxicating and of higher yield and earthen wears put a positive effect on minerals content (Roy et al., 2012; Mohamadou et al., 2008). Traditional preparation of Mbujha in earthenware pots by fermenting Hibiscus sabdariffa seeds significantly increases the aluminium, manganese, magnesium, sodium, zinc and decreases the calcium level (Mohamadou et al., 2008). It is observed that boiling of water in earthen pots decreases the heavy metal concentration in water due to soil composition (Kandavel et al., 2015). Besides boiling, cooking in earthen-were also enhances the flavonoids, crude protein, and higher acceptability (Gupta and Nagar, 2010). Food cooked in earthen cookware increases iron and zinc concentration and decreases the other toxic heavy metals during cooking (Anthony et al., 2013). Due to its low cost, many small production industries uses earthen pots for production e.g., gur or jaggery making (Pattnayak and Misra, 2004). Eating on ceramic or earthen plates is much healthier and non-toxicant than other metal and plastic plates (Trivedi et al., 2017).

\section{Soapstone}

Soapstones are metamorphic rocks rich in actinolite, dolomite and talc. It is commonly known as steatites. These are soft and easy to carve stones along with some essential thermal properties that made it effective for use in cooking as a cookware or cooking stone. These are very fragile, so they require proper and meticulous handling during cooking and washing. Due to its high density, mechanical strength and temperature resistance quality soapstone cookwares are used in cooking food that require longer cooking time. Soapstone cookwares doesn't affect the natural taste and aroma of the food besides act as a storing pot (Kora, 2020). Quintaes et al. (2011) has demonstrated that the use of soapstone cookware significantly increases the hemoglobin, hematocrit, serum iron, serum ferritin, transferrin, and transferrin saturation index (TSI) and total iron binding capacity (TIBC) in the volunteers. New or crude soapstone pans leaches $\mathrm{Al}, \mathrm{Ca}$, $\mathrm{Cd}, \mathrm{Co}, \mathrm{Cr}, \mathrm{Fe}, \mathrm{Mg}, \mathrm{Mn}, \mathrm{Ni}$ and $\mathrm{Pb}$ but later, after continuous cooking cured pans stopped contributing toxicity in food and used as mineral nutrition in food (Quintaes et al., 2002). Another study reveals that the use of soapstone cookwares and vessels in arctic regions is high because of its thermal qualities; temperature shock resistance, heat absorption and storage abilities etc. Besides, research stated that soapstone vessels are better as compared to other metal and ceramic containers (Frink et al., 2012). Soapstone cookwares are contemporary to the pottery and were used in remote time. Due to the new technological inventions and lack of availability, they become obsolete. In some southern states areas of India, these are still in use and has spread up to the tribes of Northeastern India (Wells III et al., 2014). Lack of proper research and literature on soapstone cookware is causing a gap between our traditional indigenous practices and scientific inventions, which needs to be bridged.

\section{Conclusion}

Underutilized millets are Nutri-cereals with high nutritional qualities, dietary fiber and effective in small and large scale supplements or as a fortificant. Millets are nutrients rich and contain various minerals, e.g., calcium, iron, magnesium, manganese, potassium, zinc and phosphorus. These are soothing, gluten-free, intestine friendly, and alkaline, so gluten/wheat intolerants and patients suffering with constipation can consume them. Its cells and tissue maintenance actions are effective in inflammations. Millets contain tannins, phenolic mixes, flavonoids and other important amino and fatty acids. Millets and millet products are very useful in obesity, diabetes, malnutrition, cardiovascular disease, celiac diseases, protein energy malnutrition etc. Aluminium cookwares or pressure cookers adversely affect the food quality by leaching and nutrient denaturation, while earthen cookware increases the nutrients, texture, color but not durable and causes cooking inconveniences. People are using a variety of cookwares like aluminium, earthen, iron, copper, soapstone, stainless steel etc., and all are having different advantages and disadvantages. Aluminium cookwares are the most harmful cookwares among all. This review has revealed that some of the major health issues such as chronic renal failure, cirrhosis, cancer, dermatitis, neurodegeneration etc., we are facing nowadays might be due to the shift and change in our culinary practices. Presently used cookwares are leaching some harmful chemical compounds that pose critical health issues ranging from diabetes to alzheimer and cancer. On the other side, using earthen or clay pots, copper and iron cookwares instead of aluminium pressure cooker and nonstick/anodized cookwares in cooking practices can be a great deal in combating the pre- and post- transition health problems, especially in India. However, some modifications and improvements can be helpful for increasing their acceptability.

\section{ACKNOWLEDGEMENTS}

The authors are thankful to SERB-DST (File no. ECR/2016/001893) for financial support. 


\section{Conflict of interest}

The authors declare that they have no conflict of interest.

\section{REFERENCES}

1. Al Zubaidy, E. A., Mohammad, F. S. and Bassioni, G. (2011). Effect of pH, salinity and temperature on Aluminium cookware leaching during food preparation. International Journal of Electrochemical Science, 6 (12), 6424-6441.

2. Alabi, O. A. and Adeoluwa, Y. M. (2020). Production Usage, and Potential Public Health Effects of Aluminium Cookware: A Review. Annals of Science and Technology, 5(1), 20-30.(ahead-of-print).https://doi.org/10.2478/ast2020-0003

3. Ali, M. A., El Tinay, A. H., and Abdalla, A. H. (2003). Effect of fermentation on the in vitro protein digestibility of pearl millet. Food Chemistry, 80(1), 51-54. https:// doi.org/10.1016/S0308-8146(02)00234-0

4. Ambati, K., and Sucharitha, K. V. (2019). Millets-Review on Nutritional Profiles and Health Benefits. International Journal of Recent Scientific Research, 10(7), 3394333948. https://doi.org/10.24327//JRSR.

5. Anderko, L., and Pennea, E. (2020). Exposures to per-and polyfluoroalkyl substances (PFAS): Potential risks to reproductive and children's health. Current Problems in Pediatric and Adolescent Health Care, 100760.https:// doi.org/10.1016/j.cppeds.2020.100760.

6. Annapure, U. S., Singhal, R. S., and Kulkarni, P. R. (1998). Studies on deep-fat fried snacks from some cereals and legumes. Journal of the Science of Food and Agriculture, 76(3), 377-382. https://doi.org/10.1002/(SICI)1097 -0010(199803)76:3<377::AID-JSFA957>3.0.CO;2-R

7. Anthony, B., Ojekale, C., Chukwu, G., Oladipupo, L. O., and Titilola, S. O. (2013). Some Nigerian Traditional Food Milling Techniques and Cookware Increase Concentrations of Some Heavy Metals in Lycopersicon Esculentum and Citrullus Lanatus. IOSR Journal of Pharmacy, 3(3), 613. http://www.iosrphr.org/papers/v3i3/B033106013.pdf

8. Assefa, K., Cannarozzi, G., Girma, D., Kamies, R., Chanyalew, S., Plaza-Wüthrich, S., and Tadele, Z. (2015). Genetic diversity in tef [Eragrostis tef (Zucc.) Trotter]. Frontiers in Plant Science, 6, 177. https://doi.org/10.3 389/fpls.2015.00177.

9. Baba, W. N., Rashid, I., Shah, A., Ahmad, M., Gani, A., Masoodi, F. A., and Wani, S. M. (2016). Effect of microwave roasting on antioxidant and anticancerous activities of barley flour. Journal of the Saudi Society of Agricultural Sciences, 15(1), 12-19.https://doi.org/10.1016/j.jssas.20 14.06.003

10. Bai, Q., Fan, G., Gu, Z., Cao, X., and Gu, F. (2008). Effects of culture conditions on $y$-aminobutyric acid accumulation during germination of foxtail millet (Setaria italica L.). European Food Research and Technology, 228(2), 169-175. https://doi.org/10.1007/s00217-008-0920-0.

11. Balli, D., Bellumori, M., Pucci, L., Gabriele, M., Longo, V., Paoli, P., and Innocenti, M. (2020). Does Fermentation Really Increase the Phenolic Content in Cereals? A Study on Millet. Foods, 9(3), 303.https://doi.org/10.3390/ foods 9030303

12. Bhat, R. B., Etejere, E. O., and Oladipo, V. T. (1990). Eth- nobotanical studies from central Nigeria. Economic Botany, 44(3), 382-390. https://doi.org/10.1007/BF03183923

13. Bhattacharya, P. T., Misra, S. R., and Hussain, M. (2016). Nutritional aspects of essential trace elements in oral health and disease: an extensive review. Scientifica, 5464373, 12 pages,https://doi.org/10.1155/2016/5464373

14. Birania, S., Rohilla, P., Kumar, R., and Kumar, N. (2020). Post harvest processing of millets: A review on value added products. International Journal of Chemical Studies, 8 (1),1824-1829.https://doi.org/10.22271/chemi.2020.v8.i1 aa. 8528

15. Chakrabarty, J., Sharma, G. D., and Tamang, J. P. T. (2010). Substrate utilisation in traditional fermentation technology practiced by tribes of North Cachar Hills district of Assam. Assam University Journal of Science and Technology, 4(1), 66-72. https://www.bilaspurunive rsity.ac.in/PDF/ResearchPublication s/163.pdf

16. Cheng, Y. J., and Brittin, H. C. (1991). Iron in food: effect of continued use of iron cookware. Journal of Food Science, 56(2), 584-585. https://doi.org/10.1111/j.1365-26 21.1991.tb05331.x

17. Chera, M. (2020). Tamil Traditions: Women Cooking and Eating for Heritage and Health in South India (Doctoral dissertation, Indiana University).

18. Cornejo, F., Caceres, P. J., Martínez-Villaluenga, C., Rosell, C. M., and Frias, J. (2015). Effects of germination on the nutritive value and bioactive compounds of brown rice breads. Food Chemistry, 173, 298-304. https:// doi.org/10.1016/j.foodchem.2014.10.037

19. Dan, E. U., and Ebong, G. A. (2013). Impact of cooking utensils on trace metal levels of processed food items. Annals. Food Science and Technology, 14(2), 3505. http://afst.valahia.ro/images/documente/2013/issue2/ full/section3/s03_w09_full.pdf

20. Deori, C., Begum, S. S., and Mao, A. A. (2007). Ethnobotany of Sujen---A local rice beer of Deori tribe of Assam. Indian Journal of Traditional Knowledge. 6(1), 12125. http://nopr.niscair.res.in/bitstream/123456789/841/1/ IJTK\%206\%281\%29\%20\%282007\%29\%20121-125.pdf

21. Dordevic, D., Buchtova, H., Jancikova, S., Macharackova, B., Jarosova, M., Vitez, T., and Kushkevych, I. (2019). Aluminium contamination of food during culinary preparation: Case study with Aluminium foil and consumers' preferences. Food Science \& Nutrition, 7(10), 33493360.https://doi.org/10.1002/fsn3.1204.

22. Dutta, A., Shukla, P., Tilara, S., Prasad, N., Khan, R., Suri, S., and Bharadwaj, S. B. (2019). Comparative Evaluation of Antioxidant Potential in Thermally Processed, Underutilized Food Grains of the Himalayan Region. European Journal of Nutrition \& Food Safety, 277-286.https:// doi.org/10.9734/EJNFS/2019/v9i330067.

23. Duttagupta, S. (2013). Foreign travellers' recommendation of culinary tourism in India based on cuisine image and satisfaction with experiences at culinary establishments: an exploratory study (Master's thesis, University of Waterloo).

24. Duwe, A., and Niedzwiecki, A. (2018). Aluminium toxicity in Alzheimer's disease, breast cancer and vaccine adjuvants. Journal of Cellular Medicine and Natural Health.; 1 -8. https://www.jcmnh.org/Aluminium-toxicity-in-alzheim ers-disease-breast-cancer-and-vaccine-adjuvants/

25. Dykes, L., and Rooney, L. W. (2006). Sorghum and millet 
phenols and antioxidants. Journal of Cereal Science, 44 (3), 236-251.https://doi.org/10.1016/j.jcs.2006.06.007.

26. Etejere, E. O., and Bhat, R. B. (1985). Traditional preparation and uses of cassava in Nigeria. Economic Botany, 39 (2), 157-164. https://doi.org/10.1007/BF02907839

27. Ezeji, C., and Ojimelukwe, P. C. (1993). Effect of fermentation on the nutritional quality and functional properties of infant food formulations prepared from bambarragroundnut, fluted-pumkin and millet seeds. Plant Foods for Human Nutrition, 44(3), 267-276. https:/l doi.org/10.1007/BF01088322

28. Farag, M. A., Jomaa, S. A., and El-Wahed, A. A. (2020). The Many Faces of Kefir Fermented Dairy Products: Quality Characteristics, Flavour Chemistry, Nutritional Value, Health Benefits, and Safety. Nutrients, 12(2), 346. https:// doi.org/10.3390/nu12020346

29. Frink, L., and Harry, K. G. (2008). The beauty of" ugly" Eskimo cooking pots. American Antiquity, 73(1), 103-120. https://doi.org/10.1017/S0002731600041305

30. Frink, L., Glazer, D., and Harry, K. G. (2012). Canadian Arctic soapstone cooking technology. North American Archaeologist, 33(4), 429-449. https://doi.org/10.2190/ NA.33.4.c

31. Gahlawat, P., and Sehgal, S. (1993). The influence of roasting and malting on the total and extractable mineral contents of human weaning mixtures prepared from Indian raw materials. Food Chemistry, 46(3), 253-256. https:// doi.org/10.1016/0308-8146(93)90115-V

32. Ghani, M., Kulkarni, K. P., Song, J. T., Shannon, J. G., and Lee, J. D. (2016). Soybean sprouts: A review of nutrient composition, health benefits and genetic variation. Plant Breeding and Biotechnology, 4(4), 398-412.https:// doi.org/10.9787/PBB.2016.4.4.398.

33. GHI-WHO (2019). Global Heart Initiative. Working Together to Beat Cardiovascular Disease. http://origin.who.int cardiovascular_diseases/global-hearts/GHI_Brochure.pd f.

34. GHI (2019). Global Hunger Index (GHI): India. https:// www.globalhungerindex.org/pdf/en/2019/India.pdf.

35. Griffith, L. D., and Castell $\square$ Perez, M. E. (1998). Effects of roasting and malting on physicochemical properties of select cereals and legumes. Cereal Chemistry, 75(6), 780784. https://doi.org/10.1094/CCHEM.1998.75.6.780

36. Guidetti, R., and P. Simonetti. (2000) "Materials for Cooking." A Guide to Professional Cookware, S.A.P.S., ; 1629.http://www.agnelliusa.com/download/cookinginistrume nts.pdf.

37. Gupta, V., and Nagar, R. (2010). Effect of cooking, fermentation, dehulling and utensils on antioxidants present in pearl millet rabadi-a traditional fermented food. Journal of Food Science and Technology, 47(1), 7376.https://doi.org/10.1007/s13197-010-0018-0.

38. Gupte, A., and Mumper, R. J. (2009). Elevated copper and oxidative stress in cancer cells as a target for cancer treatment. Cancer Treatment Reviews, 35(1), 3246.https://doi.org/10.1016/j.ctrv.2008.07.004.

39. Hailemariam, G. A., and Wudineh, T. A. (2020). Effect of Cooking Methods on Ascorbic Acid Destruction of Green Leafy Vegetables. Journal of Food Quality, 2020.https:// doi.org/10.1155/2020/8908670.

40. Han, J. S., Jang, S., Son, H. Y., Kim, Y. B., Kim, Y., Noh, J. H., ... and Lee, B. S. (2020). Subacute dermal toxicity of perfluoroalkyl carboxylic acids: comparison with different carbon-chain lengths in human skin equivalents and systemic effects of perfluoroheptanoic acid in Sprague Dawley rats. Archives of Toxicology, 94(2), 523-539. https:// doi.org/10.1007/s00204-019-02634-z.

41. Health Canada (2006). "The Safe Use of Cookware." It's Your Health, Majesty the Queen in Right of Canada, represented by the Ministry of Health,; 1-3. https:// cetesb.sp.gov.br/laboratorios/wp-content/uploads/sites/2 4/2013/11/utensilios_de_cozinha_ingles.pdf

42. India Health Report on Nutrition. 2015 http:// www.transformnutrition.org/india-health-report-on-nutrition -2015/india-health-report-on-nutrition-2015-explore-statelevel-data/

43. Ingle, A. P., Paralikar, P., Shende, S., Gupta, I., Biswas, J. K., da Silva Martins, L. H., and Rai, M. (2018). Copper in Medicine: Perspectives and Toxicity. In Biomedical Applications of Metals (pp. 95-112). Springer, Cham.https:// doi.org/10.1007/978-3-319-74814-6_4.

44. Ishiwata, H., Inoue, T., and Yoshihira, K. (1986). Migration of copper and some other metals from copper tableware. Bulletin of Environmental Contamination and Toxicology, 37(1), 638-642. https://doi.org/10.1007/BF0 1607816

45. Jain, S., Bhatia, G., Barik, R., Kumar, P., Jain, A., and Dixit, V. K. (2010). Antidiabetic activity of Paspalum scrobiculatum Linn. in alloxan induced diabetic rats. Journal of Ethnopharmacology, 127(2), 325-328. https://doi.or g/10.1016/j.jep.2009.10.038.

46. James, L. E. A. (2009). Quinoa (Chenopodium quinoa Wild.): composition, chemistry, nutritional, and functional properties. Advances in Food and Nutrition Research, 58, 1-31. https://doi.org/10.1016/S1043-4526(09)58001-1

47. Jiang, Z. W., Yu, W. W., Li, Y., Zhu, L., and Hu, C. Y. (2019). Migration of copper from nanocopper/ polypropylene composite films and its functional property. Food Packaging and Shelf Life, 22, 100416.https:// doi.org/10.1016/j.fpsl.2019.100416.

48. Kamerud, K. L., Hobbie, K. A., and Anderson, K. A. (2013). Stainless steel leaches nickel and chromium into foods during cooking. Journal of Agricultural and Food Chemistry, 61(39), 9495-9501.https://doi.org/10.1021/ jf402400v.

49. Kandavel, S., lyenkani, N., Kumar, M., and Junaid, M. (2015). Effect of boiling and storage in five different commonly used cooking vessels on water fluoride concentration. Der Pharmacia Lettre Journal, 7(6), 192-197. https:// www.scholarsresearchlibrary.com/articles/effect-of-boilingand-storage-in-five-different-commonly-used-cookingvessels-on-water-fluoride-concentration.pdf

50. Khetarpaul, N., and Chauhan, B. M. (1990). Effect of fermentation by pure cultures of yeasts and lactobacilli on the available carbohydrate content of pearl millet. Food Chemistry, 36(4), 287-293. https://doi.org/10.1016/03088146(90)90068-F

51. Kim, J., and Park, J. (2020). Millet vs rice: an evaluation of the farming/language dispersal hypothesis in the Korean context. Evolutionary Human Sciences, 2.https://doi.o $\mathrm{rg} / 10.1017 / \mathrm{ehs} .2020 .13$.

52. Kontoghiorghes, G. J., and Kontoghiorghe, C. N. (2020). Iron and Chelation in Biochemistry and Medicine: New Approaches to Controlling Iron Metabolism and Treating Related Diseases. Cells, 9(6), 1456. https:// 
doi.org/10.3390/cells9061456.

53. Koontz, J. L., Liggans, G. L., and Redan, B. W. (2020). Temperature and $\mathrm{pH}$ affect copper release kinetics from copper metal foil and commercial copperware to food simulants. Food Additives \& Contaminants: Part A, 37(3), 465-477.https://doi.org/10.1080/19440049.2019.1704447.

54. Kora, A. J. (2020). Traditional soapstone storage, serving, and cookware used in the Southern states of India and its culinary importance. Bulletin of the National Research Centre, 44, 1-9. https://doi.org/10.1186/s42269-020-00340 -w.

55. Krishnan, S. S., McLachlan, D. R., Krishnan, B., Fenton, S. S. A., and Harrison, J. E. (1988). Aluminium toxicity to the brain. Science of the Total Environment, 71(1), 59-64. https://doi.org/10.1016/0048-9697(88)90299-9

56. Kumar, A., Arya, R. K., Kumar, S., Kumar, D., Kumar, S., and Panchta, R. A. V. I. S. H. (2012). Advances in pearl millet fodder yield and quality improvement through breeding and management practices. Forage Research, 38, 114. http://forageresearch.in/wp-content/uploads/2013/07/1 $-14 . p d f$

57. Kumar, S. R., Sadiq, M. B., and Anal, A. K. (2020). Comparative study of physicochemical and functional properties of pan and microwave cooked underutilized millets (proso and little). LWT-Food Science and Technology, 109465.https://doi.org/10.1016/j.Iwt.2020.109465.

58. Kuo, Y. H., Rozan, P., Lambein, F., Frias, J., and VidalValverde, C. (2004). Effects of different germination conditions on the contents of free protein and non-protein amino acids of commercial legumes. Food Chemistry, 86(4), 537-545. https://doi.org/10.1016/j.foodchem.2003.09.042.

59. Li, L., Lietz, G., Bal, W., Watson, A., Morfey, B., and Seal, C. (2018). Effects of quinoa (Chenopodium quinoa Wild.) consumption on markers of CVD risk. Nutrients, 10(6), 777. https://doi.org/10.3390/nu10060777.

60. Liu, K., Zheng, J., Wang, X., and Chen, F. (2019). Effects of household cooking processes on mineral, vitamin B, and phytic acid contents and mineral bioaccessibility in rice. Food Chemistry, 280, 59-64.https://doi.org/10.1016/ j.foodchem.2018.12.053.

61. Lowndes, S. A., and Harris, A. L. (2005). The role of copper in tumour angiogenesis. Journal of Mammary Gland Biology and Neoplasia, 10(4), 299-310.https:// doi.org/10.1007/s10911-006-9003-7.

62. Malathi, B., Appaji, C., Reddy, G. R., Dattatri, K., and Sudhakar, N. (2016). Growth pattern of millets in India. Indian Journal of Agricultural Research, 50(4), 382 386. https://doi.org/10.18805/ijare.v50i4.11257.

63. Meenatchi, R., Brimapureeswaran, R., Loganathan, M., Sujeetha, A. R., and Singaravadivel, K. (2015). Effect of Microwave Treatment on Aflatoxin Content Of Maize. International Journal for Science and Advance Research in Technology.; 1(6): 125-128.

64. Menger, F., Pohl, J., Ahrens, L., Carlsson, G., and Örn, S. (2020). Behavioural effects and bioconcentration of perand polyfluoroalkyl substances (PFASs) in zebrafish (Danio rerio) embryos. Chemosphere, 245, 125573. https://doi.org/10.1016/j.chemosphere.2019.125573.

65. Michaelraj, P. S. J., and Shanmugam, A. (2013). A study on millets based cultivation and consumption in India. International Journal of Marketing, Financial Services and Management Research, 2(4), 49-58. http://
indianresearchjournals.com/pdf/IJMFSMR/2013/

April/5.pdf

66. Modgil, R., and Sood, P. (2017). Effect of roasting and germination on carbohydrates and anti-nutritional constituents of indigenous and exotic cultivars of pseudo-cereal (Chenopodium). Journal of Life Sciences, 9(1), 6470.https://doi.org/10.1080/09751270.2017.1336020.

67. Mohamadou, B. A., Mbofung, C. M., and Thouvenot, D. (2008). Bacterial fermentation induced mineral dynamics during the production of Mbuja from Hibiscus sabdariffa seeds in earthen-ware pots. Annals of Microbiology, 58(3), 447.https://doi.org/10.1007/BF03175542.

68. Mukherjee, A., Satija, D., Sinha, S., and Sarma, A. P. (2019). Food Imports in India: Prospects, Issues and Way Forward. Journal of Economic Science Research.; 02(03): 18-36. https://doi.org/10.30564/jesr.v2i3.841

69. Müller, F. D., Hackethal, C., Schmidt, R., Kappenstein, O., Pfaff, K., and Luch, A. (2015). Metal release from coffee machines and electric kettles. Food Additives \& Contaminants: Part $A, \quad 32(11), \quad 1959-1964 . h t t p s: / / d o i . o r g / 10.1$ 080/19440049.2015.1086929.

70. Nandy, A. (2004). The changing popular culture of Indian food: Preliminary notes. South Asia Research, 24(1), 919. https://doi.org/10.1177/0262728004042760.

71. Neelam, Bamji, M. S., \& Kaladhar, M. (2000). Risk of increased aluminium burden in the Indian population: contribution from aluminium cookware. Food Chemistry, 70(1), 57-61. https://doi.org/10.1016/S0308-8146(00)00068-6

72. Obadina, A., Ishola, I. O., Adekoya, I. O., Soares, A. G., de Carvalho, C. W. P., and Barboza, H. T. (2016). Nutritional and physico-chemical properties of flour from native and roasted whole grain pearl millet (Pennisetum glaucum [L.] R. Br.). Journal of Cereal Science, 70, 247-252.https:// doi.org/10.1016/j.jcs.2016.06.005.

73. Otemuyiwa, I. O., Falade, O. S., and Adewusi, S. R. A. (2018). Effect of various cooking methods on the proximate composition and nutrient contents of different rice varieties grown in Nigeria. International Food Research Journal, 25(2), 747-754. http://www.ifrj.upm.edu.my/25\% 20(02)\%202018/(42).pdf

74. Park, J., and Brittin, H. C. (2000). Iron content, sensory evaluation, and consumer acceptance of food cooked in iron utensils. Journal of Food Quality, 23(2), 205-215. https://doi.org/10.1111/j.1745-4557.2000.tb00207.x

75. Pattnayak, P. K., anjd Misra, M. K. (2004). Energetic and economics of traditional gur preparation: a case study in Ganjam district of Orissa, India. Biomass and Bioenergy, 26(1), 79-88.https://doi.org/10.1016/S0961-9534(03) 00061-8.

76. Pennington, J. A., and Schoen, S. A. (1995). Estimates of dietary exposure to aluminium. Food Additives \& Contaminants, 12(1), 119-128. https://doi.org/10.1080/026 52039509374286.

77. Pingali, P., Aiyar, A., Abraham, M., and Rahman, A. (2019). Transforming food systems for a rising India (p. 368). Springer Nature. https://doi.org/10.1007/978-3-03014409-8

78. Pradeep, P. M., and Sreerama, Y. N. (2015). Impact of processing on the phenolic profiles of small millets: Evaluation of their antioxidant and enzyme inhibitory properties associated with hyperglycemia. Food Chemistry, 169, 455 -463. https://doi.org/10.1016/j.foodchem.2014.08.010. 
79. Purewal, S. S., Salar, R. K., Bhatti, M. S., Sandhu, K. S., Singh, S. K., and Kaur, P. (2020). Solid-state fermentation of pearl millet with Aspergillus oryzae and Rhizopus azygosporus: effects on bioactive profile and DNA damage protection activity. Journal of Food Measurement and Characterization, 14(1), 150-162.https://doi.org/10.1007/ s11694-019-00277-3.

80. Quan, C. (2019). The Effect of Vinegar and Tap Water on the Release of Nickel in Grade 304 Stainless Steel Cups. Journal of the South Carolina Academy of Science, 16(2), 7. https://scholarcommons.sc.edu/jscas/ vol16/iss $2 / 7 /$

81. Quintaes, K. D., Amaya-Farfan, J., Morgano, M. A., and Mantovani, D. M. B. (2002). Soapstone (steatite) cookware as a source of minerals. Food Additives \& Contaminants, 19(2), 134-143. https://doi.org/10.1080/026 5203011006620.

82. Quintaes, K. D., Amaya-Farfan, J., Tomazini, F. M., Morgano, M. A., de Almeyda Hajisa, N. M., and Neto, J. T. (2007). Mineral migration and influence of meal preparation in iron cookware on the iron nutritional status of vegetarian students. Ecology of Food and Nutrition, 46(2), 125 -141.https://doi.org/10.1080/03670240701285079.

83. Quintaes, K. D., Haj-Isa, N. M. A., Netto, J. T., and Amaya-Farfan, J. (2011). Soapstone utensils may improve iron status in adult women. A preliminary study. Archivos Latinoamericanos de Nutricion, 61(4), 429-432. http:// ve.scielo.org/pdf/alan/v61n4/art13.pdf

84. Rao, D.B., Ananthan, R., Hariprasanna, K., Bhatt, V., Rajeswari, K., Sharma, S., and Tonapi, V.A. (2018). Nutritional and Health Benefits of Nutri Cereals. Rajendranagar, Hyderabad: Nutri hub TBI, ICAR_Indian Institute of Millets research (IIMR). 2018. . http://www.nutricere als.dac.gov.in/Publication/Pub_HealthyBenfits_Sep20 18.pdf.

85. Reardon, A. C. (2011). Discovering metals-a historical overview. Metallurgy for the non-metallurgist, 73-84. https://www.asminternational.org/documents/10192/321 2401/05306G Sample BuyNow.pdf/ab60c086-2c71-4de0 -91f6-aad1112cf4dc

86. Rittirong, A., and Saenboonruang, K. (2018). Quantification of Aluminium and heavy metal contents in cooked rice samples from Thailand markets using inductively coupled plasma mass spectrometry (ICP-MS) and potential health risk assessment. Emirates Journal of Food and Agriculture, 372-380.https://doi.org/10.9755/ejfa.2018.v3 0.15 .1680

87. Roy, A., Khanra, K., Bhattacharya, C., Mishra, A., and Bhattacharyya, N. (2012). Bakhar-Handia fermentation: General analysis and a correlation between traditional claims and scientific evidences. Advances in Bioresearch, 3(3), 28-32. http://www.soeagra.com/abr/ abrsept_2012/5.pdf

88. Saini, S., Saxena, S., Samtiya, M., Puniya, M., and Dhewa, T. 2021. Potential of underutilized millets as Nutricereal: an overview. Journal of Food Science and Technology, 1-13. https://doi.org/10.1007/s13197-021-04985-x

89. Samtiya, M., Aluko, R. E., and Dhewa, T. (2020). Plant food anti-nutritional factors and their reduction strategies: an overview. Food Production, Processing and Nutrition, 2 (1), 1-14. https://doi.org/10.1186/s43014-020-0020-5.

90. Saxena, H. O., and Dutta, P. K. (1975). Studies on the ethnobotany of Orissa. Nelumbo, 17(1-4), 124-131. http:// www.nelumbo-bsi.org/index.php/nImbo/article/view/7578 $6 / 59034$

91. Seena, S., Sridhar, K. R., Arun, A. B., and Young, C. C (2006). Effect of roasting and pressure-cooking on nutritional and protein quality of seeds of mangrove legume Canavalia cathartica from southwest coast of India. Journal of Food Composition and analysis, 19(4), 284-293.https://doi.org/10.1016/j.jfca.2005.05.004.

92. Semwal, A. D., Padmashree, A., Khan, M. A., Sharma, G. K., and Bawa, A. S. (2006). Leaching of aluminium from utensils during cooking of food. Journal of the Science of Food and Agriculture, 86(14), 2425-2430.https:// doi.org/10.1002/jsfa.2635.

93. Sharma, S., Saxena, D. C., and Riar, C. S. (2016). Analysing the effect of germination on phenolics, dietary fibres, minerals and $y$-amino butyric acid contents of barnyard millet (Echinochloa frumentaceae). Food Bioscience, 13, 60-68.https://doi.org/10.1016/j.fbio.2015.12.0 07.

94. Simi, D., and Matusitz, J. (2017). Glocalization of subway in India: How a US giant has adapted in the Asian subcontinent. Journal of Asian and African Studies, 52(5), 573-585.https://doi.org/10.1177/0021909615596764 .

95. Soibam, H., and Ayam, V. S. (2018). The traditional fermented foods of Meiteis of Manipur, India: a case study. Journal of Pharmacognosy and Phytochemistry, 7 (4), 535-539. https://www.phytojournal.com/archives/20 18/vol7issue4/PartJ/7-3-481-793.pdf

96. Srivastav, P. P., Das, H., and Prasad, S. (1990). Effect of roasting process variables on in-vitro protein digestibility of Bengal gram, maize and soybean. Food Chemistry, 35 (1), 31-37. https://doi.org/10.1016/0308-8146(90)90128Q

97. Stahl, T., Falk, S., Rohrbeck, A., Georgii, S., Herzog, C. Wiegand, A., Hotz, S., Boschek, B., Zorn, H. and Brunn, $H$. (2017). Migration of aluminium from food contact materials to food-a health risk for consumers? Part III of III: Migration of aluminium to food from camping dishes and utensils made of aluminium. Environmental Sciences Europe. https://doi.org/10.1186/s12302-017-0117-x.

98. Steenland, K., Fletcher, T., and Savitz, D. A. (2010). Epidemiologic evidence on the health effects of perfluorooctanoic acid (PFOA). Environmental Health Perspectives, 118(8), 1100-1108. https://doi.org/10.1289/ ehp.0901827

99. Street, R. A., Mathee, A., Tanda, S., Hauzenberger, C., Naidoo, S., and Goessler, W. (2020). Recycling of scrap metal into artisanal cookware in the informal sector: A public health threat from multi metal exposure in South Africa. Science of the Total Environment, 699, 134324.https://doi.org/10.1016/j.scitotenv.2019.134324.

100.Subastri, A., Ramamurthy, C., Suyavaran, A., Mareeswaran, R., Mandal, P., Rellegadla, S., and Thirunavukkarasu, C. (2015). Nutrient profile of porridge made from Eleusine coracana (L.) grains: effect of germination and fermentation. Journal of Food Science and Technology, 52(9), 6024-6030. https://doi.org/10.1007/ s13197-015-1713-7.

101.Suma, P. F., and Urooj, A. (2014). Influence of germination on bioaccessible iron and calcium in pearl millet (Pennisetum typhoideum). Journal of Food Science and 


\begin{abstract}
Technology, 51(5), 976-981.https://doi.org/10.1007/s1319 7-011-0585-8.
\end{abstract}

102.Tandon, N., Anjana, R.M., Mohan, V., Kaur, T., Afshin, A., Ong, K., Mukhopadhyay, S., Thomas, N., Bhatia, E., Krishnan, A. and Mathur, P. (2018). The increasing burden of diabetes and variations among the states of India: the Global Burden of Disease Study 1990-2016. The Lancet Global Health, 6(12), e1352-e1362.https:// doi.org/10.1016/S2214-109X(18)30387-5.

103.Tang, Q. Q., Feng, L., Jiang, W. D., Liu, Y., Jiang, J., Li, S. H. and Zhou, X. Q. (2013). Effects of dietary copper on growth, digestive, and brush border enzyme activities and antioxidant defense of hepatopancreas and intestine for young grass carp (Ctenopharyngodon idella). Biological Trace Element Research, 155(3), 370-380.https:// doi.org/10.1007/s12011-013-9785-6.

104. Thakur, M., and Tiwari, P. (2019). Millets: the untapped and underutilized nutritious functional foods. Plant Archives, 19(1), 875-883. http://plantarchives.org/PDF\% 2019-1/875-883\%20(4529).pdf

105.Trivedi, J., Soni, B., and Rahim, M. S. M. (2017). Clay Cookware and tableware: Old is Gold. Management Journal of Siva Sivani Institute of Management , 9(2): 5-24. https://www.ssim.ac.in/pdfs/IX-2.pdf\#page =5

106. UNICEF(2019). Annual report For Every Child reimagine. 2019. https://www.unicef.org/sites/default/files/2020-06/ UNICEF annual-report-2019_2.pdf.

107.UNICEF-WHO-The World Bank (2019). Joint Child Malnutrition Estimates. Levels and trends in child malnutrition, 2019.https://apps.who.int/iris/bitstream/handle/1066 5/331097/WHO-NMH-NHD-19.20-eng.pdf?ua=1.

108.Usha, B., Krishna Veni, G., Muni Kumar, D., and Hemalatha, K. P. J. (2011). Partial characterization of $\alpha$-amylase from germinating little millets (Panicum sumatrense). Journal of Phytology. 3(1): 01-08, https:// core.ac.uk/download/pdf/236017643.pdf

109.Wang, F., Jiao, P., Qi, M., Frezza, M., Dou, Q. P., and Yan, B. (2010). Turning tumor-promoting copper into an anti-cancer weapon via high-throughput chemis- try. Current Medicinal Chemistry, 17(25), 2685-2698. https://doi.org/10.2174/092986710791859315

110.Watanabe, M. (1999). Antioxidative phenolic compounds from Japanese barnyard millet (Echinochloa utilis) grains. Journal of Agricultural and Food Chemistry, 47 (11), 4500-4505. https://doi.org/10.1021/jf990498s.

111.Weidenhamer, J. D., Kobunski, P. A., Kuepouo, G., Corbin, R. W., and Gottesfeld, P. (2014). Lead exposure from Aluminium cookware in Cameroon. Science of the Total Environment, 496, 339-347.https://doi.org/10.1016/ j.scitotenv.2014.07.016.

112.Wells III, E. W., Sherwood, S. C., and Hollenbach, K. D. (2014). Soapstone vessel chronology and function in the southern Appalachians of eastern Tennessee: The Apple Barn site (40BT90) assemblage. Southeastern Archaeology, 33(2), 153-167.

113.Wokoma, E. C., and Aziagba, G. C. (2001). Sensory evaluation of Dawa Dawa produced by the traditional fermentation of African yam bean (Sphenostylis Stenocarpa Harms) Seeds. Journal of Applied Sciences and Environmental Management, 5(1). https://doi.org/10.4314/jase m.v5i1.54961

114.Wu, X., Wang, D., Bean, S. R., and Wilson, J. P. (2006). Ethanol production from pearl millet by using Saccharomyces cerevisiae. In 2006 ASAE Annual Meeting (p. 1). American Society of Agricultural and Biological Engineers. https://www.ars.usda.gov/ARSUserFiles/30200510/Publi cations-2006/2006\%20-\%20Ethanol\%20Production $\%$ 20from\%20Pearl\%20Millet.pdf

115.Yadav, D. N., Anand, T., Kaur, J., and Singh, A. K. (2012). Improved storage stability of pearl millet flour through microwave treatment. Agricultural Research, 1(4), 399-404.https://doi.org/10.1007/s40003-012-0040-8.

116. Yamijala, S. S., Shinde, R., and Wong, B. M. (2020). Real -time degradation dynamics of hydrated per-and polyfluoroalkyl substances (PFASs) in the presence of excess electrons. Physical Chemistry Chemical Physics, 22(13), 6804-6808.https://doi.org/10.1039/c9c p06 797c. 